\title{
Artigos
}

\section{Deficiência e transferência de renda diante da síndrome congênita do Zika vírus: um estudo sobre a Medida Provisória 894/2019}

Disability and income transfer in relation to congenital Zika syndrome: a study of provisional measure 894/2019 (abstract: p. 15)

Discapacidad y transferencia de renta ante el síndrome congénito del zika virus: un estudio sobre la medida provisional 894/2019 (resumen: p. 15)

Silvia de Oliveira Pereira ${ }^{(a)}$

<silvia.pereira@ufrb.edu.br>

Juliana Tosta de Oliveira ${ }^{(\mathrm{b})}$

<jutosta@hotmail.com>

Milton Silva de Vasconcellos ${ }^{(c)}$

<mintonsvasconcellos@gmail.com>

Darci Neves dos Santos ${ }^{(d)}$

<darci@ufba.br>

\author{
(a) Serviço Social, Centro de \\ Artes, Humanidades e Letras, \\ Universidade Federal do \\ Recôncavo da Bahia (UFRB). \\ Rua Maestro Irineu Sacramento, \\ s/n., Centro. Cachoeira, BA, \\ Brasil. 44300-000. \\ (b) Pós-graduanda do Programa \\ de Pós-Graduação em Ciências \\ Sociais (mestrado), UFRB. \\ Cachoeira, BA, Brasil. \\ (c) Pós-graduando do Programa \\ de Políticas Sociais e \\ Cidadania (doutorado), \\ Universidade Católica do \\ Salvador. Salvador, BA, Brasil. \\ (d) Instituto de Saúde Coletiva, \\ Universidade Federal da Bahia. \\ Salvador, BA, Brasil.
}

Desde 2015, a Síndrome Congênita do Zika Vírus (SCZV) marca o cenário brasileiro, extrapolando o campo da Saúde Pública com demandas da proteção social. Considerando a intersecção entre pobreza, deficiência e marcos da seguridade social, examina-se a Medida Provisória 894, que prevê renda mensal vitalícia para as crianças acometidas. Com o objetivo discutir o instrumento à luz dos marcos da seguridade social no recorte da transferência de renda não condicionada para as pessoas com deficiência ( $\mathrm{PCD}$ ) no Brasil, realizou-se um estudo qualitativo mediante análise de documentos públicos e revisão de literatura. As respostas estatais não produziram impacto na insuficiência de renda porque voltaram-se inicialmente para atender à situação emergencial, recorrendo às políticas preexistentes, e culminaram na substituição entre modalidades de transferência de renda - o Benefício de Prestação Continuada para Pensão Vitalícia -, revelando fragilização da proteção social integral.

Palavras-chave: Deficiência. Proteção social. Síndrome Congênita do Zika vírus. 


\section{Introdução}

Desde 2015, uma nova geração de crianças com deficiência desperta preocupações sobre políticas públicas diante da Síndrome Congênita do Zika Vírus (SCZV). A magnitude da epidemia transcende os limites da Saúde Pública, demandando açóes de proteção social articuladas ao desenvolvimento infantil e à reparação da histórica espoliação de direitos das pessoas com deficiência $(\mathrm{PcD})$.

A SCZV emerge na vigência de um contexto nacional de turbulência política e econômica que alude ao Estado mínimo e à retração do legado de direitos sociais, cumprindo tendências do neoliberalismo econômico global que aportam "medidas de desregulamentação do trabalho e a expropriação dos mecanismos públicos de

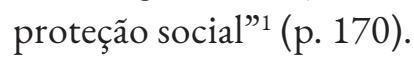

As respostas estatais relativas à proteção social foram focalizadas, desde 2016, nos benefícios socioassistenciais já previstos no arcabouço normativo, com ênfase no Benefício de Prestação Continuada (BPC), uma modalidade de transferência de renda não condicionada que alcança pessoas em situação grave de pobreza. Todavia, em 2019, emerge a Medida Provisória (MP) $894^{2}$ que substitui o BPC por pensão especial vitalícia para crianças com microcefalia associada ao $Z i k a$ vírus nascidas no ápice da epidemia.

O presente artigo indaga sobre as características da resposta estatal configurada na MP 894/2019. O objetivo é discutir o instrumento à luz dos marcos da seguridade social no recorte da transferência de renda não condicionada para as $\mathrm{PcD}$ no Brasil.

O estudo qualitativo utilizou publicações científicas e documentos públicos nacionais e internacionais sobre indicadores socioeconômicos na SCZV. Realizou-se análise de conteúdo temático da MP 894/2019 e de documentos públicos correlacionados, identificando a configuração da resposta estatal frente à transferência de renda.

Discute-se a construção social da deficiência e da seguridade social, que expressa a atuação do Estado perante desigualdades estruturais. São abordados impactos socioeconômicos da SCZV e a relação entre deficiência e pobreza. Apresenta-se uma análise da MP 894/2019 e de instrumentos normativos relacionados verificando a configuração das respostas estatais.

As ações do Estado brasileiro relativas à transferência de renda no cenário da SCZV possibilitam o debate sobre a superação ou aprofundamento das contradições e lacunas na consolidação dos direitos das $\mathrm{PcD}$.

\section{Deficiência e marcos da seguridade social}

A deficiência é compreendida na contemporaneidade como uma relação social, possibilitando uma agenda propositiva e conquistas no campo dos direitos ${ }^{3,4}$. Todavia, a deficiência foi construída sob discursos e práticas ancoradas em uma racionalidade valorativa entre corpos “normais” e corpos desviantes, uma lógica binária entre capacidade e incapacidade que resultou na condição de subalternidade para as $\mathrm{PcD}^{5-7}$ ainda persistente na atualidade. 
Identifica-se na Antiguidade e na Idade Média formas de aniquilamento das $\mathrm{PcD}$, por meio da negligência ou abandono, além do extermínio legalizado ${ }^{5,89}$. Na modernidade, a compreensão da pobreza como condição pedagógica útil ao disciplinamento para o trabalho e aceitação da autoridade ${ }^{10}$ contribuiu para estabelecer políticas e práticas higienistas, eugênicas e moralizantes que moldavam corpos e condutas 5 . O Estado e setores dominantes, a exemplo da Igreja, protagonizaram procedimentos de encarceramento que foram constituintes de um poder-saber capaz de classificar, nomear e controlar as PcD e quaisquer outras que representassem uma ameaça à ordem instituída por seu distanciamento de um padrão estabelecido como norma ${ }^{5,8}$.

O binarismo capacidade e incapacidade se aprofunda à medida que a estrutura social se erige nos ideais de corpos hígidos e habilitados para a venda da força de trabalho. No desenvolvimento do modo de produção capitalista, a deficiência expressava impossibilidade para uma vida produtiva, dada a centralidade do trabalho na relação capacidade e incapacidade.

A partir da segunda metade do século XIX, o Seguro Social, modelo contributivo financiado pelos trabalhadores e regulado pelo Estado, emerge como resposta aos riscos de interrupção da capacidade para o trabalho ${ }^{11}$. Ao longo do século XX, o Seguro Social tornou-se o núcleo central do Estado Social "e foi determinante na regulação das relaçôes econômicas e sociais”"12 (p. 324). Estabelecia-se, a partir da Europa da década 1940, a universalização de serviços sociais e a renda mínima a não contribuintes como forma de gestão da desigualdade, mantendo-se a primazia da condição de trabalhador produtivo contribuinte na condição de cidadão ${ }^{13,14}$, mas contraditoriamente responsabilizando o Estado na provisão de necessidades básicas como direito social.

No Brasil, apenas na década de 1980, a Seguridade Social adota a perspectiva de direito de cidadania. O BPC é o primeiro marco da proteção social integral ${ }^{15,16}$ configurado como transferência de renda não condicionada e não contributiva para PcD e idosos em condição grave de pobreza. Para o acesso, as PcD devem cumprir critérios de renda per capita familiar inferior a um quarto do salário-mínimo e de condições de funcionalidade que os impossibilite para o trabalho. O BPC, no valor de um salário-mínimo, é intransferível e não vitalício, pois requer reavaliação periódica em relação tanto à funcionalidade do beneficiário quanto à renda.

$\mathrm{O} \mathrm{BPC}$ significa garantia do direito à vida diante da pobreza grave ${ }^{17}$, mas também expressa o binarismo capacidade e incapacidade nos critérios de funcionalidade que não considera a histórica exclusão do trabalho, além da focalização nas necessidades básicas, apresentando um ponto de corte de renda muito baixo que exclui $\mathrm{PcD}$ também afetadas pela pobreza. Alcança situaçóes de vulnerabilidade, provendo o consumo de bens e serviços básicos, mas não supre a lacuna de provisão de rend $a^{18}$, especialmente quando se considera que os cuidados cotidianos às $\mathrm{PcD}$, especialmente crianças, impede o exercício de atividade laborativa por pelo menos um membro da família, em geral as mulheres.

Embora o BPC expresse um importante avanço no campo dos direitos, as $\mathrm{PcD}$ vivenciam exclusão estrutural e restriçóes à participação determinantes e condicionantes da pobreza, requerendo o fortalecimento da proteção social integral. Contudo, a agenda político-econômica neoliberal apresenta novas lógicas que conduzem à regressão da proteção qualificada como direito social ${ }^{13}$. 


\section{A SCZV e a relação entre deficiência e pobreza}

O vertiginoso aumento de casos de crianças com microcefalia e outras afecçóes associadas ao vírus $Z i k a$ acometeu predominantemente a região Nordeste ${ }^{19,20}$, uma das mais empobrecidas e espoliadas do Brasil. A maior prevalência ocorre nas áreas com piores níveis socioeconômicos, havendo possível associação à desnutrição proteica materna ${ }^{21}$. Tais fatos inscrevem a SCZV no cenário mais geral da relação entre deficiência e pobreza.

Apesar da restrição da literatura sobre o impacto econômico para as famílias ${ }^{22}$, estudos que utilizam variáveis socioeconômicas demonstram predominância de rendas familiares não superiores a dois salários mínimos, situação de desemprego ou trabalho informal dos provedores, mães e pais jovens, além de residência em locais com precárias condições de saneamento e acesso a serviços ${ }^{23-29}$.

A insuficiência de renda é uma das principais causas e expressão da pobreza, porém, não revela a multidimensionalidade e a complexidade do fenômeno. Propondo uma abordagem multidimensional da pobreza, Sen ${ }^{30}$ assinala os contextos de vida nos quais a falta de oferta de serviços básicos, a negação de direitos políticos, a existência de deficiência, entre outros, propiciam situaçôes de vulnerabilidade social.

O World Disability Report (WDR) aborda as condições de pobreza e privação que afetam as $\mathrm{PcD}$, destacando a escassez de recursos financeiros e a ausência ou precariedade de acesso às políticas sociais na maioria dos países do mundo ${ }^{31}$. Barnes e Sheldon ${ }^{32}$ consideram a concepção ampla de pobreza na relação com deficiência e discutem a intersecção com outras condições que favorecem o risco e a vulnerabilidade, tais como gênero e etnia. Os autores afirmam que as $\mathrm{PcD}$ são as mais pobres entre os pobres e indicam que as prescriçóes da economia neoliberal afetam as $\mathrm{PcD}$, especialmente diante da tendência à desresponsabilização do Estado com as políticas redistributivas de proteção social.

Ao alcançar a primeira infância, a SCZV torna mais crítico "o circuito de retroalimentação”33(p. 235) que mantém as $\mathrm{PcD}$ nas camadas sociais mais empobrecidas. Em relação à infância, o circuito é bidirecional, pois $43 \%$ das crianças menores de cinco anos que vivem em países pobres apresentam riscos ao seu desenvolvimento pleno ${ }^{34} \mathrm{e}$, ao mesmo tempo, a pobreza é "mais grave e, proporcionalmente, mais frequente onde a presença de crianças com deficiência é notada”35 (p. 201) ${ }^{(\mathrm{e})}$.

Pinto et al. ${ }^{36}$ demonstram uma variação negativa superior a 100\% em famílias com crianças e adolescentes em condiçôes de saúde raras e complexas - fibrose cística, mucopolissacaridoses e osteogênese imperfeita. Os gastos voltados para suprir necessidades relativas a tais condiçốes de saúde são considerados catastróficos: entre 12\% e 31\% da renda.

O Programa das Naçôes Unidas para o Desenvolvimento (PNUD) demonstra, em estudo de $2017^{37}$, que a epidemia do Zika vírus tem impacto de longo prazo e altos custos diretos e indiretos para os países, com desdobramentos mais profundos em regióes mais pobres. A ocorrência da SCZV implica em perda de produtividade devido tanto à morbidade e mortalidade prematura dos acometidos quanto ao abandono da força de trabalho dos responsáveis pelo cuidado direto, o que toca a questão de gênero, uma vez que as mulheres são as mais envolvidas no trabalho vinculado ao cuidado. (e) França ${ }^{35}$, a partir de dados do Instituto Brasileiro de Geografia e Estatística (IBGE) de 2010, indica que o percentual de domicílios em pobreza financeira segundo idade da PcD é 73,9\% para a faixa de zero a cinco anos e de $73,6 \%$ para a faixa de seis a 14 anos. Nas demais faixas, os percentuais entram em queda: 45,2\% (faixa de 15 a 64 anos) e 15,4\% (faixa de 65 anos ou mais). 
Cabral et al. ${ }^{25}$ identificam a predominância de mulheres solteiras e desempregadas como mães de crianças acometidas pela SCZV em Sergipe. O estudo de Duarte et al..$^{23}$ sobre as necessidades das crianças acometidas aponta que:

Há dificuldade para enfrentar problemas financeiros, tendo em vista que os cuidados custam caro, e na maioria dos casos é necessário que pelo menos um membro da família pare de trabalhar para cuidar do filho, porque raras são as famílias que podem pagar alguém para ajudar e, assim, a mãe torna-se a principal cuidadora. ${ }^{23}$ (p. 254)

Colón-Gonzales et al. ${ }^{38}$ estimam a carga econômica das sequelas neurológicas relacionadas à epidemia de Zika vírus de 2015/2016 em dois bilhóes de dólares por ano na América Latina e Caribe. Especificamente no recorte da SCZV, o PNUD ${ }^{37}$ afirma que os custos indiretos, envolvendo a perda de renda devido às obrigaçóes de cuidados com as crianças, foram estimados em uma faixa de quatrocentos milhóes a quatro bilhões de dólares para a região (América Latina e Caribe) no cenário de taxa de transmissão elevada do Zika.

O PNUD ${ }^{37}$ adota como componentes do cálculo os custos médicos diretos; os custos não médicos; a perda de produtividade devido à maior morbidade e mortalidade prematura; e a perda de produtividade devido ao abandono de força de trabalho por um dos pais. Assim, ao longo da vida, o custo estimado da SCZV será de 0,89 milhôes de dólares por caso e de 1.707 dólares por caso ao mês (seis vezes superior ao salário-mínimo brasileiro).

O PNUD ${ }^{37}$ afirma que os programas de transferência de renda já existentes na América Latina não serão suficientes para garantir o apoio adequado às crianças e suas famílias com vistas a retirá-las da condição de vulnerabilidade e reivindica:

[...] assistência financeira proporcional aos custos reais dos cuidados, bem como proporcionar oportunidades de subsistência para as mães em risco de abandonar permanentemente o mercado de trabalho. ${ }^{37}$ (p. 10)

\section{A MP 894/2019 e seus antecedentes: respostas em três atos}

Uma MP constitui-se em um instrumento que tem implicaçôes pragmáticas relativas ao seu efeito imediato e tem desdobramentos políticos na mobilização de debates e coalisóes em torno da matéria, pois requer aprovação no Congresso Nacional em prazo determinado $^{(\mathrm{f})}$. Ao mesmo tempo, guarda relação com atos ou vazios legislativos anteriores, não constituindo, assim, ação isolada, mas sim parte do processo de construção de um problema público que envolve múltiplos agentes e interesses em disputa.

A MP 894 de 4 de setembro de $2019^{2}$ estabelece pensão especial para as crianças com microcefalia decorrentes do Zika vírus nascidas entre 1o de janeiro de 2015 e 31 de dezembro de 2018, beneficiárias do BPC. O instrumento converte uma modalidade de transferência de renda - o BPC - para outra - a pensão especial -, com a diferença de (f) MPs são atos normativos com força de lei editadas pelo Poder Executivo para casos urgentes e relevantes que geram efeitos imediatos. Sua provisoriedade decorre do prazo de vigência de até 120 dias (sessenta dias iniciais prorrogáveis uma vez por igual período) para tramitar no Congresso Nacional, a fim de que a MP seja aprovada na íntegra ou com alteração, tornandose, incialmente, um Projeto de Lei de Conversão e submetido a votação para, em seguida, tornar-se lei ${ }^{18}$ 
ser vitalícia. Não há incidência direta sobre o impacto financeiro previsto para SCZV, pois é direcionada às mesmas crianças que já recebiam o $\mathrm{BPC}$, sem acréscimo de valores ou ampliação de acesso mediante novos critérios.

Ainda que o tema fosse tratado sob a narrativa de prioridade, não houve inovação frente a contradições históricas do BPC, a exemplo da instituição da $\mathrm{PcD}$ como destinatária do benefício e da família como núcleo para averiguação da renda, que produzem impactos relevantes para o cotidiano das famílias, particularmente para as mães, que tendem a renunciar a quaisquer ganhos ou direitos financeiros para manter o limite de corte do benefício ${ }^{39}$.

A necessidade da proteção social diante da SCZV foi vislumbrada no cenário do sobressalto da epidemia. Ainda antes da definição da etiologia ou das associaçóes, o fato social - nascimento de crianças com microcefalia em número muito superior aos índices conhecidos - estava instalado e trazia consigo o agravante da condição de pobreza capaz de afetar negativamente o desenvolvimento pleno das crianças acometidas.

A Estratégia de Ação Rápida para o Fortalecimento da Atenção à Saúde e da Proteção Social de Crianças com Microcefalia foi instituída pela portaria interministerial 405, de 15 de março de $2016^{40}$, e por instruçốes operacionais conjuntas ${ }^{41,42}$. Configurou-se uma ação emergencial para orientar a articulação entre instrumentos e dispositivos já presentes no ordenamento da política de Assistência Social com as de Saúde e Previdência Social, a exemplo de busca ativa de casos, orientaçốes, acolhimento, encaminhamentos, emissão de laudos e instrução de processos.

Esse conjunto de medidas ocorre no período crítico da epidemia e está voltado a conferir celeridade às questôes de insuficiência de renda, pobreza grave e proteção social frente ao iminente aumento da demanda.

Pereira et al. ${ }^{43}$ demonstram que em 2016 o número de concessóes de BPC para crianças com até 48 meses de idade com diagnóstico de microcefalia foi oito vezes maior do que a média de benefícios anuais na série histórica desde 2009, saltando, em números absolutos, de duzentos para 1.603. Os autores afirmam que, além do aumento, a distribuição dos casos condiz com a da epidemia de SCZV, uma vez que $73,1 \%$ destes se deram na região Nordeste.

Assim, a primeira ação pública do Estado brasileiro visava disciplinar a atividade de agentes locais, caracterizando a "mobilização e a adaptação de regras estáticas aos fatos sociais” ${ }^{44}$ (p. 84).

Posteriormente, a Lei n. 13.301, de 27 de junho de $2016^{45}$ - cuja origem é a MP 712 de janeiro $2016^{46}$ e que trata de ações no âmbito da vigilância em saúde relacionado a situaçôes de perigo iminente para transmissão de dengue, Chikungunya e Zika - traz, em seu artigo 18, além da extensão para 180 dias da licença e salário-maternidade para as mães de crianças acometidas pela SCZV, a determinação de concessão de BPC por um período máximo de três anos para as crianças acometidas, denominando-o de BPC Temporário.

A MP 712/2016 $6^{46}$, também editada no momento crítico da epidemia, não contemplou a transferência de renda ou de qualquer outro benefício socioassistencial ou previdenciário, focalizando exclusivamente açôes de vigilância à saúde com ênfase ao acesso a imóveis abandonados pela autoridade sanitária. 
O BPC e o impacto financeiro da SCZV não compuseram a intencionalidade da MP 712/2016 ${ }^{46}$ e, igualmente, não foram temas centrais nas 108 emendas propostas pelos parlamentares durante o período dos debates dessa MP. Contudo, nove dessas propostas de emendas são concernentes às áreas da política social mais próximas à proteção social: uma sobre educação, indicando a prioridade das crianças acometidas; sete relacionadas à extensão de licença e salário-maternidade ou à redução de jornada de trabalho para responsáveis pelas crianças; e uma sobre concessão de indenização por danos morais e pensão vitalícia para as vítimas da Síndrome de Guillain-Barré e microcefalia associadas ao $Z$ ika vírus.

A emergência de temas sobre educação, cuidados a serem prestados diretamente pelas famílias - com ênfase na função materna -, direitos trabalhistas e indenização no debate público de uma MP sobre vigilância da saúde revela uma tentativa de levantar questões sobre política social e configurar o problema público.

A Lei n. 13.30145, cuja ementa delimita o escopo à vigilância da saúde, incorpora, no artigo 18, o BPC, a licença-maternidade e o salário-maternidade no artigo, conformando, a despeito da relevância dos temas, uma cauda legislativa ${ }^{(\mathrm{g})}$ por seu conteúdo ser distinto da MP que a originou, violando assim tanto o devido processo legal quanto o princípio democrático, segundo entendimento do Supremo Tribunal Federal (STF) por ocasião do julgamento da Ação Direta de Inconstitucionalidade (ADI) 5127:

1. Viola a Constituição da República, notadamente o princípio democrático e o devido processo legislativo (arts. 1o, caput, parágrafo único, 2o, caput, 5o, caput, e LIV, CRFB), a prática da inserção, mediante emenda parlamentar no processo legislativo de conversão de medida provisória em lei, de matérias de conteúdo temático estranho ao objeto originário da medida provisória ${ }^{48}$.

A despeito do artigo $4^{\circ}$ da Resolução $1 / 2002^{49(h)}$ do Congresso Nacional, na qual é expressamente vedada a prática das caudas legislativas, o artigo 18 da Lei n. $13.301^{45}$ trata de dois temas da seguridade social em uma norma sobre vigilância da saúde. Todavia, o artigo 18 é mais representativo por demonstrar a negatividade da proteção social integral e da seguridade social que, per si, não foram construídas como problemas públicos e políticos relacionados à SCZV. Ou seja, apesar da existência do fato social, a temática não alcançou o espaço público ao ponto de configurar um problema digno de uma solução a ser empreendida pelo poder público ${ }^{44}$, emergindo apenas como uma cauda legislativa.

Além disso, o BPC foi tratado como a solução que encontra o problema ${ }^{50}$, pois o artigo 18 reafirma o que já está definido na Lei Orgânica da Assistência Social ${ }^{16}$. Apresenta também redundância, ao adjetivar o benefício como temporário, e erro, ao estabelecer restrição para sua vigência por três anos, antes inexistente.

A exposição de motivos (EMI 082/2019) ${ }^{51}$ para o terceiro ato sobre o tema, a MP $894 / 2019$, toma exatamente esse problema da Lei n. $13.301^{45}$ como argumento central da sua relevância e urgência, passados os três anos, afirmando na alínea 10 que: (g) "A expressão 'cauda legislativa' também chamada de 'rabilongos' ou 'contrabando legislativo' por Rui Barbosa, referese à inclusão de matéria estranha ao objeto originário do Projeto de Lei, com vistas a inserir tais matérias sem chamar a atenção do assunto inserido"47 (p. 134).

(h) Texto normativo que trata sobre os procedimentos para tramitação das MPs. 
Os requerentes devem se submeter às mesmas regras do $\mathrm{BPC}$ regular para acessar o benefício temporário. Assim, a única diferença efetiva entre o BPC regular e o benefício temporário, em suma, é a de que este impõe limite de três anos para permanência no benefício. Na prática, o benefício temporário não foi, portanto, implementado ${ }^{51}$. (p. 4)

Um elemento, contudo, que não é explícito diz respeito ao fato das crianças com SCZV já terem demonstrado desafiar as perspectivas iniciais e viverem para além dos três anos de idade, o que fará vir à tona "a precariedade em termos de rede intersetorial articulada e pronta para recebê-las" ${ }^{52}$ (p. 2).

A justificativa de uma necessária correção na norma anterior levanta o tema proteção social diante da SCZV e traz para o centro da MP elementos referentes à Política de Assistência Social. O novo ato suprime o artigo 18 da Lei n. $13.301^{45}$ como solução ao problema apontado, mas estabelece pensão vitalícia como ação indenizatória apenas para os beneficiários do BPC e em substituição a este.

O estabelecimento de pensão vitalícia implica no reconhecimento por parte do Estado do impacto de longo prazo de um fenômeno frente ao qual assume posição de reparação dada a omissão ou ação criminosa. Os antecedentes na recente história brasileira de pensão vitalícia de caráter indenizatório na área de Saúde se referem à vigilância da saúde e à violação de direitos humanos nos casos da Síndrome de Talidomida (Lei n. 7.070/82), das vítimas fatais da hemodiálise de Caruaru (Lei n. 9.422/96), das vítimas do acidente Césio-137 em Goiânia (Lei n. 9.425/96) e das pessoas com hanseníase submetidas à internação e tratamento compulsórios (Lei n. 11.520/07).

A apresentação das pensões antecedentes como parte da justificativa para a pensão vitalícia no escopo da MP 894 permite afirmar que a ação convoca o Estado a assumir o seu papel indenizatório diante do impacto de longo prazo do grave problema de saúde pública em foco. Nessa direção, exige a desistência de ação judicial indenizatória contra o Estado por parte dos beneficiários ${ }^{(i)}$ e onera a programação orçamentária das indenizações e pensões especiais de responsabilidade da União, sem haver comprometimento significativo de gastos, dada a substituição de um benefício por outro.

A MP 894/2019² recortou, assim, dois problemas distintos: a transferência de renda mediante BPC qualificada a partir do erro na norma anterior e a pensão como ação indenizatória devido a um problema grave de saúde pública. Apresentou, contudo, uma única solução caracterizada na substituição do BPC por pensão vitalícia. Esse único ato desconsiderou a transferência de renda como parte da proteção social para as $\mathrm{PcD}$ em condição de pobreza já prevista na política de Assistência Social vigente e debilitou a função indenizatória frente ao problema de saúde pública de grande magnitude, dada a restrição do acesso aos mesmos beneficiários do BPC.

Justificou-se, além da indisponibilidade de recursos para exercício pleno da função indenizatória do Estado, que a mudança de BPC para pensão permitirá que a família, ao alcançar eventualmente aumento da renda mediante ingresso no mundo

\footnotetext{
(i) Tal exigência amplia a possibilidade de gerar iniquidade, uma vez que famílias com renda superior ao ponto de corte do BPC não fazem jus à pensão e poderão mover ação indenizatória.
} 
do trabalho, não tenha risco de perda do benefício. Evidencia-se também que um dos problemas centrais do $\mathrm{BPC}$ - o baixo ponto de corte de renda - não foi tratado na resposta à SCZV, tampouco tem sido enfrentado como um problema público no recorte da relação entre pobreza e deficiência.

Data de 1996 um Projeto de Lei voltado para a alteração da renda familiar per capita para acesso ao BPC de um quarto para meio salário-mínimo ${ }^{53}$. Em março de 2020, a Lei n. $13.981^{54}$ é publicada com essa alteração; contudo, o STF acata a Arguição de Descumprimento de Preceito Fundamental $662^{55}$ com pedido de medida cautelar proposta pela Presidência da República, impedindo a vigência da lei sob alegação de criação de despesa sem a indicação da estimativa do seu impacto orçamentário e financeiro.

Verifica-se que o precário debate sobre pobreza e deficiência na sociedade brasileira está alinhado à tendência da regressão da proteção social como direito de cidadania e dever do Estado transferindo para os cidadãos requerentes a responsabilidade pelo seu sustento ${ }^{13}$.

Em relação à tramitação, a MP 894, de 4 de setembro de 2019², estava no Congresso Nacional desde 5 de outubro de 2019 e, utilizando a prerrogativa da prorrogação, seu prazo para deliberação findou em fevereiro de 2020. Nesse período, foi composta Comissão Mista (Câmara e Senado), cujos trabalhos culminaram em sua conversão na Lei n. $13.895^{56}$ em abril de 2020 .

Foram realizadas três audiências públicas e examinadas 144 emendas, das quais cinco foram acatadas (uma total e quatro parcialmente) para o texto final, produzindo alteraçóes relativas à correção da denominação da patologia de microcefalia para SCZV e ao período de nascimento dos beneficiários, de 1o de janeiro de 2015 e 31 de dezembro de 2018 para 1o de janeiro de 2015 e 31 de dezembro de 2019.

Não foram acatadas emendas que implicassem em preservação dos pilares da transferência de renda não condicionada para as crianças acometidas ou quaisquer possibilidades de aumento de gastos como a manutenção de $\mathrm{BPC}$ adicionado à pensão indenizatória, ou ampliação do acesso à pensão vitalícia. Ainda que a justificativa, nos discursos realizados em plenária e no relatório final da comissão, reconheça a existência de questôes relativas ao impacto econômico da SCZV e do ponto de corte para acesso ao BPC, reafirmou-se o discurso de austeridade fiscal, que adquire força no cenário internacional desde a década de 1990.

\section{Considerações finais}

A SCZV, por sua magnitude, exigiu celeridade de respostas científicas e estatais, alcançando êxito no estabelecimento da associação com o agente, vetor e modos de transmissão da doença no desenvolvimento de tecnologias para o diagnóstico e prevenção, bem como na direção do fomento à pesquisa e à formação profissional ${ }^{57,58}$. Em sentido amplo, constituiu:

[...] um fato social total [...] que reflete uma multiplicidade de fatos e significados que vão desde a relação estabelecida com o mosquito (um ser não humano) a um dos atos humanos mais básicos, o nascimento ${ }^{59}$. (p. 225) 
Tal situação projeta preocupaçôes com o desenvolvimento infantil, inclusive por ser transversalizado pela relação complexa entre pobreza e deficiência.

Contudo, a insuficiência de renda, a vulnerabilidade e o risco social das crianças com SCZV não encontraram solução no âmbito do Estado. A despeito da constatação do aumento da demanda por BPC e de outras evidências da condição de pobreza das crianças acometidas, a ação estatal transitou entre a redundância e a negação de direitos e o impacto financeiro da SCZV foi secundarizado mediante justificativa de austeridade fiscal.

A MP 894/2019², ao estabelecer a substituição do BPC por uma pensão vitalícia, adotou uma perspectiva de negatividade sobre o dever constitucional do Estado brasileiro no provimento de condições de vida digna das $\mathrm{PcD}$ mediante transferência de renda não condicionada, prevista desde a Constituição de $1988^{15}$. Promove-se uma ruptura com o primeiro marco brasileiro para a proteção social integral, o BPC, ao mesmo tempo que as conquistas emancipatórias das $\mathrm{PcD}$ são colocadas sob ameaça.

\section{Contribuições dos autores}

Todos os autores participaram ativamente de todas as etapas de elaboração do manuscrito.

\section{Financiamento}

Estudo vinculado ao Projeto de Pesquisa Edital MCTIC/FNDCT-CNPq/MEC-CAPES/ MS-Decit/n. 14/2016 "Efeitos das manifestações neurológicas congênitas associadas ao Zika vírus sobre o desenvolvimento cognitivo infantil: um estudo de coorte prospectiva no contexto da Atenção Básica, em Salvador - BA”, financiado pelo CNPq processo n. 440650/2015-1 - Prevenção e Combate ao vírus Zika.

\section{Conflito de interesse}

Os autores não têm conflito de interesse a declarar.

\section{Direitos autorais}

Este artigo está licenciado sob a Licença Internacional Creative Commons 4.0, tipo BY (https://creativecommons.org/licenses/by/4.0/deed.pt_BR).

\section{(cc) BY}

Editora

Rosamaria Carneiro

Editora associada

Fátima Oliver

\section{Submetido em}

28/03/20

Aprovado em

$11 / 01 / 21$ 


\section{Referências}

1. Mota AE. Expropriações contemporâneas: hipóteses e reflexões. In: Boschetti I, organizador. Expropriação e direitos no capitalismo. São Paulo: Cortez; 2018. p. 167-86.

2. Brasil. Presidência da República. Medida Provisória no 894, de 4 de Setembro de 2019. Institui pensão especial destinada a crianças com microcefalia decorrente do Zika Vírus, nascidas entre 1o de janeiro de 2015 e 31 de dezembro de 2018, beneficiárias do Benefício de Prestação Continuada. Diário Oficial da União. 5 Set 2019.

3. Dhanda A. Construindo um novo léxico dos direitos humanos: Convenção sobre os Direitos das Pessoas com Deficiências. Sur Rev Int Direitos Human. 2008; 5(8):42-59.

4. Brasil. Coordenadoria Nacional para Integração da Pessoa Portadora de Deficiência. A Convenção sobre Direitos das Pessoas com Deficiência Comentada. Brasília: Secretaria Especial dos Direitos Humanos; 2008.

5. Lobo LF. Os infames da história: pobres, escravos e deficientes no Brasil. Rio de Janeiro: Lamparina; 2009.

6. Aguado-Diaz AL. História de las deficiencias. Madrid: Escuela Libre Editorial, Fundacion Once; 1995.

7. Pereira SO. Para não ser o etecetera. Cruz das Almas: EDUFRB; 2018.

8. Aranha MSF. Paradigmas da relação da sociedade com as pessoas com deficiência. Rev Ministerio Publico Trab. 2001; (21):160-73.

9. Freitas MNC. A inserção de pessoas com deficiência em empresas Brasileiras. Um estudo sobre as relaçôes entre concepçóes de deficiência, condições de trabalho e qualidade de vida no trabalho [tese]. Belo Horizonte: Centro de Pós-Graduação e Pesquisas em Administração, Faculdade de Ciências Econômicas, UFMG; 2007.

10. Fleury S. Estado sem cidadãos: seguridade social na América Latina. Rio de Janeiro: Editora Fiocruz; 1994.

11. Behring E. Fundamentos de política social. In: Mota AES, Gomes L, Bravo MIS, Teixeira M, Marsiglia RMG, Uchôa R. Serviço social e saúde. 2a ed. São Paulo: OPAS; 2007. p. 13-48.

12. Boschetti I. A política de seguridade social no Brasil. In: CFESS/Abepss. Serviço social: direitos sociais e competências profissionais. Brasília: CFESS/Abepss; 2009. p. 323-38.

13. Pereira CP. Proteção social no capitalismo: crítica a teorias e ideologias conflitantes. São Paulo: Cortez; 2016.

14. Boschetti I. Seguridade social e trabalho: paradoxos na construção das políticas de previdência e assistência social no Brasil. Brasília: Letras Livres; 2006.

15. Constituição (1988). Constituição da República Federativa do Brasil. Brasília (DF): Senado Federal;1988.

16. Brasil. Presidência da República. Lei no 8.742, de 7 de Dezembro de 1993. Dispóe sobre a organização da Assistência Social e dá outras providências. Diário Oficial da União. 8 Dez 1993.

17. Medeiros M, Diniz D, Barbosa L. Deficiência e igualdade. Brasília: Letras Livres; 2010.

18. Santos W. Deficiência e BPC: o que muda na vida das pessoas atendidas? Cienc Saude Colet. 2011; 16 Supl 1:787-96. 
19. França GVA, Pedi VD, Garcia MHO, Carmo GMI, Leal MB, Garcia LP. Síndrome congênita associada à infecção pelo vírus Zika em nascidos vivos no Brasil: descrição da distribuição dos casos notificados e confirmados em 2015-2016. Epidemiol Serv Saude. 2018; 27(2):e2017473.

20. Diniz D. Zika: do Sertão nordestino à ameaça global. Rio de Janeiro: Civilização Brasileira; 2016.

21. Barbeito-Andrés, Pezzuto P, Higa LM, Dias AA, Vasconcelos JM, Santos TMP, et al. Congenital Zika syndrome is associated with maternal protein malnutrition. Sci Adv. 2020; 6(2):1-12.

22. Brunoni D, Blascovi-Assis SM, Osório AAC, Seabra AG, Amato CAH, Teixeira MCTV, et al. Microcefalia e outras manifestaçôes relacionadas ao vírus Zika: impacto nas crianças, nas famílias e nas equipes de saúde. Cienc Saude Colet. 2016; 21(10):3297-302.

23. Duarte JS, Santos LOF, Sette GCS, Santos TFC, Alves FAP, Coriolano-Marinus MWL. Necessidades de crianças com síndrome congênita pelo Zika vírus no contexto domiciliar. Cad Saude Colet. 2019; 27(3):249-56.

24. Félix VPSR, Farias AM. Microcefalia e dinâmica familiar: a percepção do pai frente à deficiência do filho. Cad Saude Publica. 2018; 34(12):e00220316.

25. Cabral CM, Nóbrega MEB, Leite PL, Souza MSF, Teixeira DCP, Cavalcante TF, et al. Descrição clínico-epidemiológica dos nascidos vivos com microcefalia no estado de Sergipe, 2015. Epidemiol Serv Saude. 2017; 26(2):245-54.

26. Silva MAS, Soares AMJ, Pereira GT, Alves PJ. Microcefalia relacionada ao vírus Zika e dinâmica familiar: perspectiva da mãe. Av Enferm. 2019; 37(1):38-46.

27. Cruz TAR, Santos EMS, Silva FC, Reis MCS, Silva ACD. Perfil sociodemográfico e participação paterna nos cuidados diários de crianças com microcefalia. Cad Bras Ter Ocup. 2019; 27(3):602-14.

28. Souza AI, Siqueira MT, Ferreira ALCG, Freitas CU, Bezerra ACV, Ribeiro AG, et al. Geography of microcephaly in the zika era: a study of newborn distribution and socio-environmental indicators in Recife, Brazil, 2015-2016. Public Health Rep.2018; 133(4):461-71.

29. Vargas A, Saad E, Dimech GS, Santos RH, Sivini MAVC, Albuquerque LC, et al. Characteristics of the first cases of microcephaly possibly related to Zika virus reported in the Metropolitan Region of Recife, Pernambuco State, Brazil. Epidemiol Serv Saude. 2016; 25(4):691-700.

30. Sen A. Desenvolvimento como liberdade. São Paulo: Companhia das Letras; 2000.

31. Organização Mundial da Saúde. Relatório mundial sobre deficiência [Internet]. São Paulo: SEDPcD; 2012 [citado 25 Set 2019]. Disponível em: http://www. pessoacomdeficiencia.sp.gov.br/usr/share/documents/

32. Barnes C, Sheldon A. Disability, politics and poverty in a majority world context. Disabil Soc. 2010; 25(7):771-82.

33. Souza FR, Pimentel AM. Pessoas com deficiência: entre necessidades e atenção à saúde. Cad Ter Ocup. 2012; 20(2):229-37.

34. Lancet. Apoiando o desenvolvimento na primeira infância: da ciência à difusão em grande escala [Internet]. Lancet. 2016 [citado 18 Dez 2019]. (Sumário executivo da série do The Lancet). Disponível em: https://www.who.int/maternal_child_ adolescent/documents/ecd-lancet-exec-summary-pr.pdf?ua $=1$ 
35. França THPM. Deficiência e pobreza no Brasil: a relevância do trabalho das pessoas com deficiência [tese]. Coimbra: Faculdade de Economia da Universidade de Coimbra; 2014.

36. Pinto M, Madureira A, Barros LBP, Nascimento M, Costa ACC, Oliveiroa NV, et al. Cuidado complexo, custo elevado e perda de renda: o que não é raro para as famílias de crianças e adolescentes com condiçốes de saúde raras. Cad Saude Publica. 2019; 35(9):e00180218.

37. Programa das Naçóes Unidas para o Desenvolvimento. Uma avaliação do impacto socioeconômico do vírus Zika na América Latina e Caribe: Brasil, Colômbia e Suriname como estudos de caso [Internet]. Brasília: PNUD; 2017 [citado 9 Out 2019]. Disponível em: www.latinamerica.unpd.org

38. Colón-Gonzales FJ, Peres CA, São Bernardo CS, Hunter PR, Lake IR. After the epidemic: Zika Virus projections for Latin America and the Caribbean. PLos Negl Trop Dis. 2017; 11(11):e0006007.

39. Matos SS, Quadros MT, Silva ACR. A negociação do acesso ao Benefício de Prestação Continuada por crianças com Síndrome Congênita do Zika Vírus em Pernambuco. Anu Antropol. 2019; 44(2):229-60.

40. Brasil. Portaria Interministerial no 405, de 15 de Março de 2016. Institui, no âmbito do Sistema Único de Saúde (SUS) e do Sistema Único de Assistência Social (SUAS), a Estratégia de Ação Rápida para o Fortalecimento da Atenção à Saúde e da Proteção Social de Crianças com Microcefalia. Diário Oficial da União. 16 Mar 2016.

41. Brasil. Instrução Operacional Conjunta no 1, de 25 de Fevereiro de 2016. Diário Oficial da União. 11 Abr 2016.

42. Brasil. Instrução Operacional Conjunta no 2, de 31 de Março de 2016. Diário Oficial da União. 11 Abr 2016.

43. Pereira EL, Bezerra JC, Brant JL, Araújo WN, Santos LMP. Perfil da demanda e dos Benefícios de Prestação Continuada (BPC) concedidos a crianças com diagnóstico de microcefalia no Brasil. Cienc Saude Colet. 2017; 22(11):3557-3566.

44. Lascoumes P, Le Galès P. Sociologia da Ação Pública. Maceió: Edufal; 2012.

45. Brasil. Lei 13.301, de 17 de Junho de 2016. Dispóe sobre a adoção de medidas de vigilância em saúde quando verificada situação de iminente perigo à saúde pública pela presença do mosquito transmissor do vírus da dengue, do vírus chikungunya e do vírus da zika; e altera a Lei no 6.437, de 27 de Junho de 2016. Diário Oficial da União. 28 Jun 2016.

46. Brasil. Medida Provisória no 712, de 29 de Janeiro de 2016. Dispõe sobre a adoção de medidas de vigilância em saúde quando verificada situação de iminente perigo à saúde pública pela presença do mosquito transmissor do Vírus da Dengue, do Vírus Chikungunya e do Zika Vírus. Diário Oficial da União. 1 Fev 2016.

47. Temer M. Elementos de direito constitucional. 11a ed. São Paulo: Malheiros; 1995.

48. Brasil. Superior Tribunal Federal. ADI 5127 [Internet]. Brasília; 2016 [citado 28 Set 2019] Disponível em: http://portal.stf.jus.br/processos/detalhe.asp?incidente $=4580410$

49. Brasil. Câmara dos Deputados. Regimento Interno, estabelecido pela Resolução 1/002 CN. Dispõe sobre a apreciação, pelo Congresso Nacional, das Medidas Provisórias a que se refere o art. 62 da Constituição Federal, e dá outras providências [Internet]. Brasília; 2002 [citado 28 Set 2019] Disponível em: https://www2.camara.leg.br/legin/ fed/rescon/2002/resolucao-1-8-maio-2002-497942-normaatualizada-pl.html

50. Kingdon J. Agendas, alternatives and public policies. 2a ed. New York: Addison Wesley Longman; 1995. 
51. Brasil. Câmara dos Deputados. Medida Provisória 894, de 4 de Setembro de 2019. Institui pensão especial destinada a crianças com microcefalia decorrente do Zika Vírus, nascidas entre 1o de janeiro de 2015 e 31 de Dezembro de 2018, beneficiárias do Benefício de Prestação Continuada [Internet]. Brasília; 2019 [citado 28 Out 2019]. Disponível em: https://www2.camara.leg.br/legin/fed/medpro/2019/ medidaprovisoria-894-4-setembro-2019-789069-norma-pe.html

52. Sá MRC, Vieira ACD, Castro BSM, Agostini O, Smythe T, Kuper H, et al. De toda maneira tem que andar junto: ações intersetoriais entre saúde e educação para crianças vivendo com a síndrome congênita do vírus Zika. Cad Saude Publica. 2019; 35(12):e00233718.

53. Brasil. Senado Federal. Projeto de Lei 55, de 1996. Altera o parágrafo terceiro do art. 20 da lei 8.742, de 7 de Dezembro de 1993 [Internet]. Brasília; 1996 [citado 28 Out 2019]. Disponível em: https://www25.senado.leg.br/web/atividade/materias/-/materia/1204

54. Brasil. Lei 13.981, de 23 de Março de 2020. Altera a Lei no 8.742, de 7 de Dezembro de 1993 (Lei Orgânica da Assistência Social), para elevar o limite de renda familiar per capita para fins de concessão do benefício de prestação continuada. Diário Oficial da União. 24 Mar 2020.

55. Brasil. Advocacia Geral da União. ADPF 662 [Internet]. Brasília; 2020 [citado 28 Nov 2020]. Disponível em: http://portal.stf.jus.br/processos/detalhe. asp? incidente $=5880970$

56. Brasil. Lei 13.895, de 7 de Abril de 2020. Institui pensão especial destinada a crianças com Síndrome Congênita do Zika Vírus, nascidas entre 1o de janeiro de 2015 e 31 de dezembro de 2019, beneficiárias do Benefício de Prestação Continuada (BPC). Diário Oficial da União. 7 Abr 2020.

57. Duarte E, Garcia LP. Pesquisa e desenvolvimento para o enfrentamento da epidemia pelo vírus Zika e suas complicaçốes. Epidemiol Serv Saude. 2016; 25(2):231-2.

58. Garcia LP, Duarte E. Evidências da vigilância epidemiológica para o avanço do conhecimento sobre a epidemia do vírus Zika. Epidemiol Serv Saude. 2016; 25(4):679-81.

59. Silva ACR, Matos SS, Quadros MT. Economia Política do Zika: realçando relaçôes entre Estado e cidadão. Rev AntHropol. 2017; 28(1):223-46. 
Since 2015, Congenital Zika Syndrome (CZS) has been a feature of the Brazilian context and has moved beyond public health to demands for social protection. Given the intersection between poverty, disability and the social security framework, we examine Provisional Measure 894, which provides a lifetime monthly income for affected children. We conduct a qualitative study, analysing public documents and reviewing the literature, in order to discuss this instrument in the light of social security frameworks for unconditional cash transfers for People with Disabilities (PwD) in Brazil. State responses did not have an impact on income insufficiencies, since they were initially intended to respond to emergency situations and referred to pre-existing policies; this culminated in an income transfer modality, the Continuous Cash Benefit, being replaced by a Lifetime Pension, demonstrating a weakening of comprehensive social protection.

Keywords: Disability. Social protection. Congenital zika syndrome

Desde 2015 el Síndrome Congénito del Zika Virus (SCZV) marca el escenario brasileño, extrapolando el campo de la salud pública con demandas de la protección social. Considerando la intersección entre pobreza, discapacidad y marcos de la seguridad social, se examina la Medida Provisional 894 que prevé renta mensual vitalicia para los nińos afectados. Con el objetivo de discutir el instrumento a la luz de los marcos de la seguridad social en el recorte de la transferencia de renta no condicionada para las Personas con Discapacidad (PcD) en Brasil, se realizó un estudio cualitativo mediante análisis de documentos públicos y revisión de literatura. Las respuestas estatales no causaron impacto en la insuficiencia de renta porque inicialmente se enfocaron para atender la situación de emergencia recurriendo a las políticas preexistentes y que culminaron en la substitución entre modalidades de transferencia de renta, el Beneficio de Prestación Continua para Pensión Vitalicia, revelando la fragilización de la protección social integral.

Palabras clave: Deficiencia. Protección social. Síndrome congénito del zika virus. 